\title{
Incidental gynaecological malignancy in women who underwent hysterectomy for utero-vaginal prolapse: a 3-year institutional case study
}

\author{
Fathima Seles M.*, Rajavelu Indira
}

Department of Pathology, Madras Medical College, Chennai, Tamil Nadu, India

Received: 17 June 2018

Accepted: 24 July 2018

\section{*Correspondence:}

Dr. Fathima Seles M.,

E-mail: dr.fathimaseles@gmail.com

Copyright: (c) the author(s), publisher and licensee Medip Academy. This is an open-access article distributed under the terms of the Creative Commons Attribution Non-Commercial License, which permits unrestricted non-commercial use, distribution, and reproduction in any medium, provided the original work is properly cited.

\begin{abstract}
Background: Pelvic organ prolapse is common is almost 50\% of women over the age of 50years. The objective of the present study was to estimate the number of incidental gynaecological malignancies in women who underwent hysterectomy for utero-vaginal prolapse.

Methods: 354 women who presented with asymptomatic utero-vaginal prolapse were included in this study. Women who were symptomatic with bleeding per vaginum, lower abdominal pain or excessive white discharge and preoperative screening tests such as VIA/VILI, colposcopy, Pap smear and radio-imaging showing any gynaecological lesions were excluded from this study.

Results: Histopathological examination of the hysterectomy specimen showed premalignant lesion in 13 cases accounting to $3.7 \%$ (11 cases of CIN I, 1 case of CIN II, 1 case of CIN III) and malignant lesions in 5cases accounting for $1.4 \%$ ( 4 cases of endometrial adenocarcinoma and 1 case of cervical squamous cell carcinoma).

Conclusions: Asymptomatic women with utero-vaginal prolapse may have pre-existing premalignant and malignant lesions. Therefore, all women undergoing hysterectomy should be preoperatively screened with transvaginal ultrasound, endometrial biopsy and pap smear to rule out malignancy, as the management differs for patients with coexisting gynecological malignancies.
\end{abstract}

Keywords: Asymptomatic women, Cervical carcinoma, Endometrial carcinoma, Gynecological malignancies, Hysterectomy, Incidental, Unexpected, Utero-vaginal prolapse

\section{INTRODUCTION}

Pelvic organ prolapse is common is almost $50 \%$ of women over the age of 50 years. ${ }^{1,2}$ The incidence of unexpected gynecological malignant and premalignant lesions among asymptomatic women who underwent hysterectomy for uterovaginal prolapse varies between $0.7 \%$ and $2.6 \%$ according to literature. ${ }^{1,3}$ Women is said to be asymptomatic when they do not present with the symptoms, such as bleeding per vaginum, lower abdominal pain or excessive white discharge. ${ }^{4}$ The incidence of co-existing malignancy is increased among the elderly women and risk peaks between the age group of 75-85 years old. ${ }^{5}$

\section{METHODS}

Over a span of three years, from May 2015 to April 2018, 417 women have undergone hysterectomy for uterovaginal prolapse in a tertiary care centre at Kasturbai Gandhi Hospital, Chennai. Their medical records were assessed. Their mean age was 57.5 \pm 22.5 years $(35-80$ 
years). The most common age group undergoing hysterectomy for uterine prolapse was 55 - 65 years. $4.5 \%$ of women had stage I prolapse, $16.7 \%$ had stage II prolapse, $44.3 \%$ had stage III prolapse and remaining $34.5 \%$ had stage IV prolapse. Women who were symptomatic with bleeding per vaginum, lower abdominal pain or excessive white discharge and preoperative screening tests such as VIA/VILI, colposcopy, pap smear and radioimaging studies showing any gynaecological lesions were excluded from this study.

\section{Table 1: Surgical procedures performed for utero-} vaginal prolapse.

\begin{tabular}{|ll|}
\hline Surgical procedure & Total \\
\hline Hysterectomy with pelvic floor repair & $228(64.4 \%)$ \\
\hline Vaginal hysterectomy & $61(17.2 \%)$ \\
\hline $\begin{array}{l}\text { Hysterectomy with pelvic floor repair } \\
\text { with continence repair surgeries }\end{array}$ & $20(5.6 \%)$ \\
\hline $\begin{array}{l}\text { Hysterectomy with bilateral } \\
\text { salphingectomy pelvic floor repair }\end{array}$ & $18(5.1 \%)$ \\
\hline $\begin{array}{l}\text { Total abdominal hysterectomy } \\
\text { Hysterectomy with bilateral salphingo- } \\
\text { oophorectomy }\end{array}$ & $15(4.2 \%)$ \\
\hline $\begin{array}{l}\text { Hysterectomy with bilateral } \\
\text { salphingectomy }\end{array}$ & $6(1.7 \%)$ \\
\hline $\begin{array}{l}\text { Laproscopy assisted vaginal } \\
\text { hysterectomy }\end{array}$ & $1(0.3 \%)$ \\
\hline
\end{tabular}

417 women underwent hysterectomy for utero-vaginal prolapse. 1 woman was excluded since she was a known case of carcinoma breast in post MRM, post chemotherapy status. 12 women were excluded since they presented with abnormal uterine bleeding for around two months. 6 women were excluded since they presented with excessive white discharge per vaginum. 7 women were excluded since they presented with lower abdominal pain. 4 women were excluded because of abnormal colposcopy findings. 3 women were excluded since they had VIA/VILI positive lesions. 1 woman was excluded because her pap smear revealed low-grade squamous intraepithelial lesion (LSIL). 8 women were excluded because their endometrial thickness $>8 \mathrm{~mm}$. 18 women were excluded because their ultrasound (USG) abdomen revealed hypoechoic lesion in the uterus. 1 woman was excluded because her hysteroscopy revealed cervical polyp. 1 woman was excluded because computed tomogram (CT) abdomen showed nodules in the adnexa. 1 woman was excluded because magnetic resonance imaging (MRI) scan revealed fibroid uterus.

Therefore 63 cases in total were excluded and the study was conducted on the 354 asymptomatic women who underwent hysterectomy for uterovaginal prolapse.

\section{RESULTS}

Retrospective study was conducted on the 354 asymptomatic women who underwent hysterectomy for uterovaginal prolapse. On microscopic examination of the macroscopically normal hysterectomy specimens 13 cases showed premalignant lesions accounting to $3.7 \%$ (11cases of CIN I, 1 case of CIN II, 1 case of CIN III) and 5cases showed malignant lesions accounting for $1.4 \%$ ( 4 cases of endometrial adenocarcinoma and 1 case of cervical squamous cell carcinoma).

The details of the five unexpected uterine malignancies in asymptomatic women who underwent hysterectomy for uterovaginal prolapse are given in the table below:

Table 2: Incidence of gynecological pathologies coexisting with utero-vaginal prolapse.

\begin{tabular}{|c|c|c|c|}
\hline $\begin{array}{l}\text { Pathologic } \\
\text { condition }\end{array}$ & $\begin{array}{l}\text { Pre- } \\
\text { menopausal }\end{array}$ & $\begin{array}{l}\text { Post- } \\
\text { menopausal }\end{array}$ & Total \\
\hline Leiomyoma & $4(1.1 \%)$ & $31(8.7 \%)$ & $35(9.9 \%)$ \\
\hline Adenomyosis & $22(6.2 \%)$ & $26(7.3 \%)$ & $48(13.6 \%)$ \\
\hline $\begin{array}{l}\text { Leiomyoma } \\
\text { with } \\
\text { adenomyosis }\end{array}$ & $6(1.7 \%)$ & $3(0.8 \%)$ & $9(2.5 \%)$ \\
\hline $\begin{array}{l}\text { Endometrial } \\
\text { polyp }\end{array}$ & $1(0.3 \%)$ & $11(3.1 \%)$ & $12(3.4 \%)$ \\
\hline $\begin{array}{l}\text { Endocervical } \\
\text { polyp }\end{array}$ & $2(0.6 \%)$ & $1(0.3 \%)$ & $3(0.8 \%)$ \\
\hline $\begin{array}{l}\text { Disorderly } \\
\text { proliferative } \\
\text { endometrium }\end{array}$ & $3(0.8 \%)$ & $5(1.4 \%)$ & $8(0.8 \%)$ \\
\hline $\begin{array}{l}\text { Simple } \\
\text { hyperplasia } \\
\text { without } \\
\text { atypia }\end{array}$ & $4(1.1 \%)$ & $2(0.6 \%)$ & $6(1.7 \%)$ \\
\hline $\begin{array}{l}\text { Complex } \\
\text { hyperplasia } \\
\text { without } \\
\text { atypia }\end{array}$ & $2(0.6 \%)$ & - & $2(0.6 \%)$ \\
\hline $\begin{array}{l}\text { Endometrial } \\
\text { carcinoma }\end{array}$ & - & $4(1.1 \%)$ & $4(1.1 \%)$ \\
\hline $\begin{array}{l}\text { Chronic } \\
\text { cervicitis }\end{array}$ & $82(23 \%)$ & $260(\%)$ & $\begin{array}{l}342 \\
(96.6 \%)\end{array}$ \\
\hline CIN I & $3(0.8 \%)$ & $8(2.2 \%)$ & $11(3.1 \%)$ \\
\hline CIN II & - & $1(0.3 \%)$ & $1(0.3 \%)$ \\
\hline CIN III & $1(0.3 \%)$ & - & $1(0.3 \%)$ \\
\hline $\begin{array}{l}\text { Cervical } \\
\text { carcinoma }\end{array}$ & - & $1(0.3 \%)$ & $1(0.3 \%)$ \\
\hline $\begin{array}{l}\text { Chronic } \\
\text { vaginitis }\end{array}$ & - & $1(0.3 \%)$ & $1(0.3 \%)$ \\
\hline $\begin{array}{l}\text { Chronic } \\
\text { salphingitis }\end{array}$ & $8(0.8 \%)$ & $11(3.1 \%)$ & $19(5.4 \%)$ \\
\hline $\begin{array}{l}\text { Simple } \\
\text { serous cyst }\end{array}$ & $1(0.3 \%)$ & $1(0.3 \%)$ & $2(0.6 \%)$ \\
\hline $\begin{array}{l}\text { Follicular } \\
\text { cyst }\end{array}$ & $2(0.6 \%)$ & $5(1.4 \%)$ & $7(1.9 \%)$ \\
\hline $\begin{array}{l}\text { Corpus luteal } \\
\text { cyst }\end{array}$ & $1(0.3 \%)$ & $2(0.6 \%)$ & $3(0.8 \%)$ \\
\hline $\begin{array}{l}\text { Mucinous } \\
\text { cystadenoma }\end{array}$ & $1(0.3 \%)$ & - & $1(0.3 \%)$ \\
\hline $\begin{array}{l}\text { Papillary } \\
\text { serous } \\
\text { cystadenoma }\end{array}$ & $1(0.3 \%)$ & - & $1(0.3 \%)$ \\
\hline
\end{tabular}


Table 3: Details of the women with unexpected gynecological malignancies.

\begin{tabular}{|c|c|c|c|c|c|}
\hline Bx. No & Age & Procedure done & Hormonal status & Stage of Prolapse & Histopathological diagnosis \\
\hline $1058 / 18$ & 55 & $\begin{array}{l}\text { Vaginal hysterectomy } \\
\text { with pelvic floor repair }\end{array}$ & Post Menopause & $\begin{array}{l}4^{\text {th }} \text { degree with } \\
\text { cystocoele and } \\
\text { rectocoele }\end{array}$ & $\begin{array}{l}\text { Well differentiated infiltrating } \\
\text { endometrial adenocarcinoma, grade } \\
\text { I }\end{array}$ \\
\hline $1079 / 18$ & 60 & $\begin{array}{l}\text { Vaginal hysterectomy } \\
\text { with pelvic floor repair }\end{array}$ & Post Menopause & $\begin{array}{l}4^{\text {th }} \text { degree with } \\
\text { cystocoele and } \\
\text { rectocoele }\end{array}$ & $\begin{array}{l}\text { Moderately differentiated } \\
\text { infiltrating endometrial } \\
\text { adenocarcinoma, grade II }\end{array}$ \\
\hline $76 / 18$ & 60 & $\begin{array}{l}\text { Vaginal hysterectomy } \\
\text { with pelvic floor repair }\end{array}$ & Post Menopause & $3^{\text {rd }}$ degree & $\begin{array}{l}\text { Well differentiated infiltrating } \\
\text { endometrial adenocarcinoma, grade } \\
\text { I }\end{array}$ \\
\hline $3212 / 17$ & 72 & $\begin{array}{l}\text { Vaginal hysterectomy } \\
\text { with pelvic floor repair }\end{array}$ & Post Menopause & $\begin{array}{l}4^{\text {th }} \text { degree with } \\
\text { cystocoele and } \\
\text { rectocoele }\end{array}$ & $\begin{array}{l}\text { Poorly differentiated infiltrating } \\
\text { endometrial adenocarcinoma, grade } \\
\text { III }\end{array}$ \\
\hline $704 / 18$ & 55 & $\begin{array}{l}\text { Vaginal hysterectomy } \\
\text { with pelvic floor repair }\end{array}$ & Post Menopause & $3^{\text {rd }}$ degree & $\begin{array}{l}\text { Poorly differentiated infiltrating } \\
\text { squamous cell carcinoma of cervix, } \\
\text { grade III }\end{array}$ \\
\hline
\end{tabular}

The premalignant lesions of the cervix occurred in $2.5 \%$ of postmenopausal women whereas only $1.1 \%$ in premenopausal women. The malignant lesions both endometrial adenocarcinoma and cervical squamous cell carcinoma occurred only in postmenopausal women.

The premalignant lesions (13/13 cases) $100 \%$ found in the $3^{\text {rd }}$ degree of uterovaginal prolapse. The malignant lesions in $3 / 5$ cases $(60 \%)$ were found in the $4^{\text {th }}$ degree of uterovaginal prolapse and $2 / 5$ cases $(40 \%)$ in $3^{\text {rd }}$ degree of prolapse cases. Therefore, both the premalignant and malignant lesions were found during the advanced stages of uterovaginal prolapse.

\section{DISCUSSION}

The incidence of unexpected gynecological malignant and premalignant lesions among asymptomatic women who underwent hysterectomy for uterovaginal prolapse varies between $0.7 \%$ and $2.6 \%$ according to literature. ${ }^{1,3}$ In a retrospective study conducted with 170 women, progression from endometrial hyperplasia to carcinoma was noted, $1 \%$ in case of simple hyperplasia without atypia and $29 \%$ in case of complex hyperplasia with atypia. ${ }^{2}$ Hence if the endometrial thickness is $11 \mathrm{~mm}$ or more, even in asymptomatic post-menopausal women, endometrial biopsy should be done to rule out malignancy. ${ }^{2}$ Women is said to be asymptomatic when they do not present with the symptoms, such as bleeding per vaginum, lower abdominal pain or excessive white discharge. ${ }^{4}$

Renganathan et al. in a retrospective study, found that among the 517 asymptomatic women who underwent hysterectomy for uterovaginal prolapse, $0.8 \%$ women had endometrial carcinoma. Therefore, the study has concluded that preoperative transvaginal ultrasound is necessary to assess the endometrial thickness followed by endometrial sampling in case of thickened endometrium. ${ }^{6}$
Frick et al in a retrospective study found that among the 421 post-menopausal women with asymptomatic uterovaginal prolapse who underwent surgery, $0.2 \%$ had endometrial carcinoma and $2.6 \%$ had endometrial hyperplasia. Therefore, the study has concluded that although the risk of unexpected malignancy is low, this risk can be prevented by preoperative endometrial biopsy and transvaginal ultrasound. ${ }^{7}$

Salmon et al. in a study conducted over one year with 854 hysterectomy specimens has concluded that routine histopathological examination of hysterectomy specimens of both pre and post-menopausal cases are necessary to rule out the unexpected malignancies. ${ }^{8}$

Ramm et al. in a study found 5 out of 708 patients, that is $0.6 \%$ of the patients had unexpected endometrial carcinoma and 4 out of these 5 cases were negative for the preoperative screening tests. ${ }^{9}$ Mahnert et al reported that there is no direct association between gynecological malignancies and uterovaginal prolapse. ${ }^{10}$

Almost half of the prolapse patients had co existing uterine leiomyomas. ${ }^{11,12}$ Vaginal hysterectomy is the most common surgical procedure done for the management of uterovaginal prolapse. However, patients with co-existing malignant lesion would be best treated by vaginal hysterectomy with bilateral salphingooophorectomy and pelvic floor repair with peritoneal washings for cytological analysis. ${ }^{13}$ Hence transvaginal ultrasound and endometrial biopsy prior to surgery is necessary to rule out malignancy.

\section{CONCLUSION}

The risk of missing an unexpected gynecological malignancy is low. However, all asymptomatic women who are planned for hysterectomy should be preoperatively screened using transvaginal ultrasound on 
routine basis and endometrial biopsy, pap smear if necessary, as the management differs for patients with endometrial/ cervical carcinoma and in cases of endometrial hyperplasias.

Funding: No funding sources

Conflict of interest: None declared

Ethical approval: The study was approved by the Institutional Ethics Committee

\section{REFERENCES}

1. Elbiaa AMA, Abdelazim IA, Farhali MM, Hussain $\mathrm{M}$, Omu AE. Unexpected premalignant gynecological lesions in women undergoing vaginal hysterectomy for utero-vaginal prolapse. Menopause Review.2015;14(3):188-91.

2. Grigoriadis T, Valla A, Zacharakis D, Protopapas A, Athanasiou S. Vaginal hysterectomy for uterovaginal prolapse: what is the incidence of concurrent gynecological malignancy?. Int Urogynecol $\mathrm{J}$. 2015;26(3):421-5.

3. Renganathan A, Edwards R, Duckett JR. Uterus conserving prolapse surgery-what is the chance of missing a malignancy?. Int Urogynecol J. 2010;21(7):819-21.

4. Wan OY, Cheung RY, Chan SS, Chung TK. Risk of malignancy in women who underwent hysterectomy for uterine prolapse. Aus NZ J Obstet Gynaecol. 2013;53(2):190-6.

5. Vanichtantikul A, Tharavichitkul E, Chitapanarux I, Chinthakanan O. Treatment of Endometrial Cancer in Association with Pelvic Organ Prolapse. Case Reports Obstet Gynecol. 2017;2017.

6. Yoshino K, Kobayashi E, Endo M, Kakuda M, Okada A, Tomimatsu T, et al. A case of laparoscopic surgery for endometrial cancer in a patient previously treated with a transvaginal mesh procedure for pelvic organ prolapse. Gynecol Minimally Inv Therap. 2017;6(4):211-3.

7. Frick AC, Walters MD, Larkin KS, Barber MD. Risk of unanticipated abnormal gynecologic pathology at the time of hysterectomy for uterovaginal prolapse. Am J Obstet Gynecol. 2010;202(5):507-e1.

8. Salmon HA, Smith JH, Balsitis M. Is microscopic assessment of macroscopically normal hysterectomy specimens necessary?. J Clin Pathol. 2002;55(1):678.

9. Ramm O, Gleason JL, Segal S, Antosh DD, Kenton KS. Utility of preoperative endometrial assessment in asymptomatic women undergoing hysterectomy for pelvic floor dysfunction. Int Urogynecol $\mathrm{J}$. 2012;23(7):913-7.

10. Mahnert N, Morgan D, Campbell D, Johnston C, AsSanie S. Unexpected gynecologic malignancy diagnosed after hysterectomy performed for benign indications. Obstet Gynecol. 2015;125(2):397-405.

11. Foust-Wright C, Weinstein MM, Pilliod R, Posthuma R, Wakamatsu MM, Pulliam SJ. Uterine Pathology in Hysterectomies Performed for Treatment of Pelvic Organ Prolapse. J Minim Inv Gynecol. 2014;21(6):S95-6.

12. Mahajan G, Kotru M, Batra M, Gupta A, Sharma S. Usefulness of histopathological examination in uterine prolapse specimens. Aus NZ J Obstet Gynaecol. 2011;51(5):403-5.

13. Cliby WA, Dodson MK, Podratz KC. Uterine prolapse complicated by endometrial cancer. Am J Obstet Gynecol. 1995;172(6):1675-83.

Cite this article as: Seles FM, Indira R. Incidental gynaecological malignancy in women who underwent hysterectomy for utero-vaginal prolapse: a 3-year institutional case study. Int J Reprod Contracept Obstet Gynecol 2018;7:3625-8. 